\title{
INFLUENCE OF COMPLIANCE CRITERIA ON THE VALUE OF RELIABILITY INDEX
}

\section{SKRZYPCZAK ${ }^{1}$, L. BUDA-OŻÓG ${ }^{2}$}

\begin{abstract}
Statistical conformity criteria for the compressive strength of concrete are a matter of debate. The criteria can have prejudicial effects on construction quality and reliability. Hence, the usefulness of statistical criteria for the small sample size $n=3$ is questioned. These defects can cause a reduction in the quality of produced concrete and, consequently, too much risk for the recipient (investor). For this reason, the influence of conformity control on the value of the reliability index of concrete and reinforced concrete has been determined. The authors limited their consideration to the recommended standards PN-EN 206-1, PN-EN 1992 and ISO 2394 method of reliability index, which belongs to the analytical methods FORM (First Order Reliability Method). It assumes that the random variables are defined by two parameters of the normal distribution or an equivalent normal: the mean and the standard deviation. The impact of conformity control for $\mathrm{n}=3$ for concrete structures, designed according to the Eurocode 1992, for which the compressive strength of concrete is the capacity dominant parameter (sensitivity factor of dominating resistance parameter according to the FORM is 0.8 ), has been deternined by evaluation of the reliability index.
\end{abstract}

Keywords: conformity control, reliability index, concrete, reinforced concrete structures

\section{INTRODUCTION}

The characteristic compressive strength of concrete during the design of concrete structures is taken into account, as this can affect the fulfilment of the ultimate limit state and serviceability specified in PN-EN 1992 [5]. In the process of construction, which should be consistent with the

\footnotetext{
${ }^{1}$ PhD., Eng., Rzeszow University of Technology, Faculty of Civil and Environmental Engineering and Architecture, Ul. Poznańska 2, 35-084 Rzeszow, Poland, e-mail: izas@prz.edu.pl

${ }^{2}$ PhD., Eng., Rzeszow University of Technology, Faculty of Civil and Environmental Engineering and Architecture, Ul. Poznańska 2, 35-084 Rzeszow, Poland, e-mail: lida@prz.edu.pl
} 
requirements of PN-EN 13670 [6] concerning the execution of concrete works, a built-in construction material is monitored to ensure it fulfils the requirements fixed in the design specifications. Building material estimation is based on the principles established in the PN-EN 206-1 [7] concerning concrete. Conformity control must be exercised by the manufacturer of theconcrete. The above mentioned control is based on a compliance assessment of properties. Depending on the degree of mutual confidence between the recipient and the manufacturer, the criteria may constitute the only required procedure of acceptance for delivery. Additional study for acceptance includes only compressive strength tests, performed only when there are no doubts or if the design specifications require it. The purpose of the study is to confirm whether the additionally tested concrete batch belongs to the same population which the manufacturer had made an assessment of compliance.

Compliance criteria for the number of samples $n=3$ have many well-identified disadvantages which may result in the reduction of produced concrete quality and high-risk of recipients (investors, users). As a result, the impact of conformity control on the reliability index value of concrete structures and the reliability index value for the elements of reinforced structures were determined.

This effect for concrete structures designed according to Eurocode 1992 [5], for which the dominant parameter of resistance is the compressive strength of concrete (sensitivity factors $\alpha_{i}=0.8$ assumed), was determined by calculating the reliability index.

The reliability index for concrete structures designed according to Eurocode 1992 [5], for which the dominant parameter of resistance is the compressive strength of concrete (sensitivity factors $\alpha_{i}=0.8$ assumed), was determined. It should be noted that this analysis has been limited to the method of reliability index $\beta$ and belongs to the analytical methods FORM (First Order Reliability Method) and was recommended in PN-EN 1990 [8] and ISO 2394 [9]. This method assumes that random variables are specified using two parameters of the normal or equivalent distribution. They are described by mean value and standard deviation.

This article is an attempt to answer the question of how safe concrete and reinforced concrete structures by conformity control of concrete according PN-EN 206-1 [7] are. The effect of quality control on the safety level is most often not considered in calculations, although this is an important consideration when designing or evaluating performance-based concrete structures. 


\section{DISADVANTAGES OF COMPILANCE CRITERIA}

The identified disadvantages of code conformity criteria mainly concern the analysis of a batch (volume) of concrete before control. These analyses apply to the level of defectiveness during continuous production of concrete and are described by the relation between the probability of acceptance and defectiveness for produced concrete (OC curves). This study does not apply to the characteristic compressive strength of concrete after built-in, in other words defectiveness after compliance control. The estimation of the characteristic value of the compressive strength of concrete is dependent on the defectiveness fraction of concrete after conformity control. The defectiveness fraction of concrete after control is dependent on conformity criteria formulated and recommended in the PN-EN 206-1 [7]. Conformity criteria should be a compromise between the requirements of safety and quality. They should guarantee the characteristic compressive strength $\mathrm{f}_{\mathrm{ck}}$ is obtained. The Average Outgoing Quality (AOQ) curve is constructed by determining a series of point pairs (w, AOQ) from a series of assumed fraction defective values $\mathrm{w}$ and $\mathrm{P}_{\mathrm{a}} \cdot \mathrm{w}$ (just as in the OC curve) [1]. Note that the plot of AOQ shows the relation between the incoming quality (defective fraction before conformity control) and the outgoing quality (defective fraction after conformity control). Another important value, the average outgoing quality limit (AOQL) is simply the maximum of the AOQ curve. It represents the maximum possible percent defective for the sampling plan that is defined by conformity control. AOQ curves can be a form of presentation of the risks associated with the use of code conformity criteria for the quality control of ready-mixed concrete. The basis for the classification of concrete and determination of its quality is the characteristic compressive strength $\mathrm{f}_{\mathrm{ck}}$ after 28 days. The $\mathrm{f}_{\mathrm{ck}}$ value is defined as the $5 \%$ fractile of the statistical distribution of the compressive strength of concrete, therefore the maximum value of AOQ should be related to the value of 0.05 (Eq. 2.1).

$$
\mathrm{AOQ}=\mathrm{w} \cdot \mathrm{Pa} \leq 0.05
$$

Using AOQ curves to the verify discrimination power of conformity control recommended by PNEN 206-1 for the sample size $n=3$, it can be seen that the shape of the curves AOQ depends on the standard deviation - Fig. 1. The average outgoing quality after conformity control is higher for the greater value of the standard deviation of the compressive strength of concrete. The average outgoing quality limit (AOQL) after compliance control for conformity criteria recommended by [6] for $\mathrm{n}=3$ 
is dependent on the value of the standard deviation. For the standard deviation above $3 \mathrm{MPa}$, the average outgoing quality limit after conformity control is greater than 0.05 , and so is greater than the value recommended for $f_{\text {ck }}$ fractile -Fig. 1 .

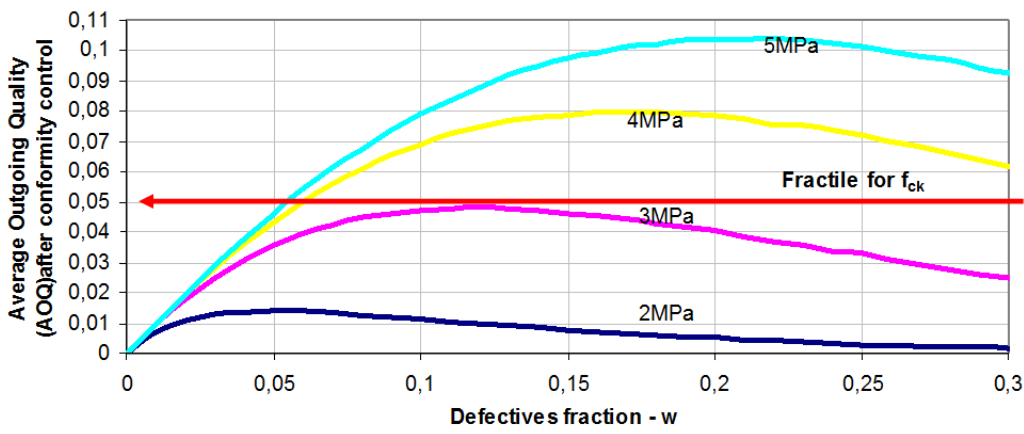

Figure. 1. AOQ curve for conformity criteria for sample size $\mathrm{n}=3$ and different standard deviation

The average outgoing quality after conformity control for concrete with the standard deviation greater than $3 \mathrm{MPa}$ built into the structure is greater than 0.05 . Concrete produced with the standard deviation above $3 \mathrm{MPa}$, though it complies with the criteria imposed during conformity control by [1], its average outgoing quality after control is greater than the 5\% fractile for the statistical distribution of the compressive strength defined in the standard [6]. When analyzing the correctness of code conformity criteria recommended for sample size $n=3$, the greater risk is on the side of mixed concrete recipient. The compliance criteria proposed in [6] can lead to too much risk for the client (the investor) by not providing sufficient quality and reliability of concrete and reinforced concrete structures. According to the assumptions for Eurocode 2 [5] developed by Rackwitz's [3] research, the compressive strength of the concrete standard deviation of $5 \mathrm{MPa}$ was assumed. Regardless of the number of the sample size for $5 \mathrm{MPa}$, the standard deviation should be a 0.05 fractile for the characteristic compressive strength. The form of conformity criteria for $n=3$ proposed in the standard [7] is correct for the standard deviation of $3 \mathrm{MPa}$. For a larger standard deviation of the compressive strength, the verified concrete does not fulfill the requirements of the proposed class of concrete. As a result of the above mentioned disadvantages of standard conformity criteria, the effect of quality control for the sample size $n=3$ on the level of safety and the reliability index value for concrete and reinforced concrete structures has been analyzed. 


\section{COMPLIANCE CRITERIA AND LEVEL OF SAFETY FOR CONCRETE CONSTRUCTION}

According to Eurocode 1990 [8], the design compressive strength $f_{c d}$ is equal to the characteristic strength $\mathrm{f}_{\mathrm{ck}}$ divided by the partial factor $\gamma_{\mathrm{c}}=1.4$. Under that assumption, Eq. 3.1 for the level of safety for concrete structures can be written as $[8,9]$ :

$$
\mathrm{f}_{\mathrm{cd}}=\mathrm{f}_{\mathrm{cm}}-\alpha_{\mathrm{i}} \cdot \beta \cdot \sigma \Rightarrow \beta=\frac{\mathrm{f}_{\mathrm{cm}}-\frac{\mathrm{f}_{\mathrm{ck}}}{1.4}}{0.8 \cdot \sigma}
$$

The level of safety for realized concrete structures of the conformity criteria for $\mathrm{n}=3$ can be similarly written as (Eq. 3.2):

$$
\beta=\frac{\mathrm{f}_{\mathrm{cm}}-\frac{\left(\mathrm{f}_{\mathrm{cm}}-4\right)}{1.4}}{0.8 \cdot \sigma}
$$

A margin of safety is related with a probability of failure of the element or a structure in equation (Eq. 3.3):

$$
\mathrm{P}_{\mathrm{f}}=\Phi(-\beta)
$$

where:

$\Phi(\ldots)$ - Laplace's function

A structure can be regarded as safe if the calculated value of the reliability index according to the formula (3.4) is not less than the target $\beta$-value:

$$
\beta \geq \beta_{\mathrm{d}}
$$

The recommended minimum target reliability index $\beta_{\mathrm{d}}$ - value for ULS for structures with different 
reliability classes and reference periods $\mathrm{T} 0=1$ year and 50 years are given in Annex B to PN-EN 1990 [8]. This reasoning adopted the performance of structural components RC2 class and in accordance with Annex C to PN EN 1990 [8], adopted the target value $\beta_{d}=3.8\left(P_{f d}=7.23\right.$ E-05). The level of safety was determined for nine concrete classes -Table 1 . The impact of conformity control for the sample size $n=3$ is particularly noticeable for concrete classes C8/10 to C30/37 and the standard deviation greater than 2.0 MPa. The index value for the reliability of the standard deviation to $2.0 \mathrm{MPa}$ is always greater than the value of $\beta=3.8$ recommended for the reliability class RC2.

In the analyzed cases, it can be seen that control of compliance has a significant impact on the safety of concrete structures whose safety is dependent on the characteristic compressive strength -Table 1.

Table 1 . The value of the reliability index $\beta$ defined for the conformity criteria for the sample size

$\mathrm{n}=3$ and the different classes of concrete

\begin{tabular}{|c|c|c|c|c|c|c|c|c|c|c|}
\hline \multirow{2}{*}{$\begin{array}{c}\text { Standard } \\
\text { deviation } \\
(\mathrm{MPa})\end{array}$} & \multicolumn{10}{|c|}{ Strength classes } \\
\cline { 2 - 14 } & $\mathrm{C} 8 / 10$ & $\mathrm{C} 12 / 15$ & $\mathrm{C} 16 / 20$ & $\mathrm{C} 20 / 25$ & $\mathrm{C} 25 / 30$ & $\mathrm{C} 30 / 37$ & $\mathrm{C} 35 / 45$ & $\mathrm{C} 40 / 50$ & $\mathrm{C} 50 / 60$ & $\mathrm{C} 80 / 95$ \\
\hline 1.5 & 4.87 & 5.83 & 6.78 & 7.73 & 8.92 & 10.11 & 11.30 & 12.49 & 14.87 & 22.02 \\
\hline 2.0 & 3.80 & 4.52 & 5.23 & 5.94 & 6.84 & 7.73 & 8.62 & 9.52 & 11.30 & 16.66 \\
\hline 3.0 & 2.73 & 3.21 & 3.68 & 4.16 & 4.75 & 5.35 & 5.94 & 6.54 & 7.73 & 11.30 \\
\hline 3.5 & 2.42 & 2.83 & 3.24 & 3.65 & 4.16 & 4.67 & 5.18 & 5.69 & 6.71 & 9.77 \\
\hline 4.0 & 2.19 & 2.55 & 2.91 & 3.27 & 3.71 & 4.16 & 4.61 & 5.05 & 5.94 & 8.62 \\
\hline 4.86 & 1.91 & 2.20 & 2.50 & 2.79 & 3.16 & 3.53 & 3.89 & 4.26 & 5.00 & 7.20 \\
\hline 5.0 & 1.87 & 2.16 & 2.44 & 2.73 & 3.09 & 3.44 & 3.80 & 1.16 & 4.87 & 7.02 \\
\hline
\end{tabular}

The analysis of the impact of conformity control on the reliability index value for realized concrete structures are presented for $\mathrm{C} 25 / 30$ concrete class and for different standard deviations. In the analyzed cases, it can be seen that conformity control has a significant impact on the value of the reliability index of concrete structures (Fig. 2a- 2e).

The impact of conformity control is particularly evident in the case where deviation is stabilized at $5 \mathrm{MPa}$. According to this (8) (Eq.3.5):

$$
\beta=3.09<\beta_{d}=3.8
$$

The resulting value of the reliability index $\beta=3.44$ is the smaller of the minimum value 3.8 of the reliability index for resistance for the adopted reference period of 50 years. Realized structures of concrete class $\mathrm{C} 20 / 25$ on the basis of conformity criteria for $n=3$ are not safe structures. The probability of failure of ultimate limit states are greater than the maximum allowable probability of failed structure (Eq.3.6): 


$$
\mathrm{P}_{\mathrm{f}}=2.91 \mathrm{E}-04>\mathrm{P}_{\mathrm{fd}}=7.23 \mathrm{E}-05
$$

a)

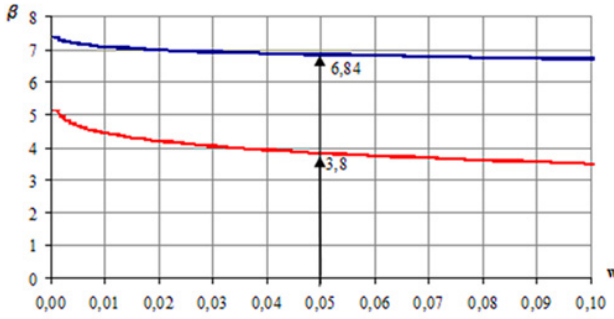

c)

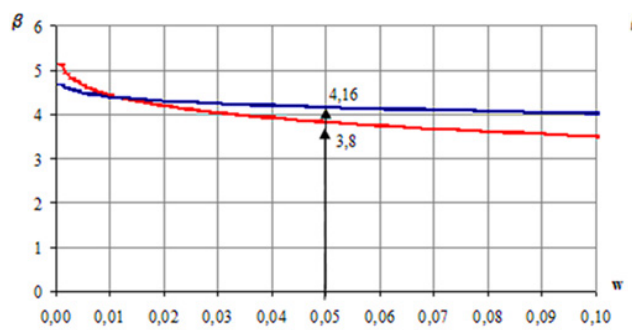

e)

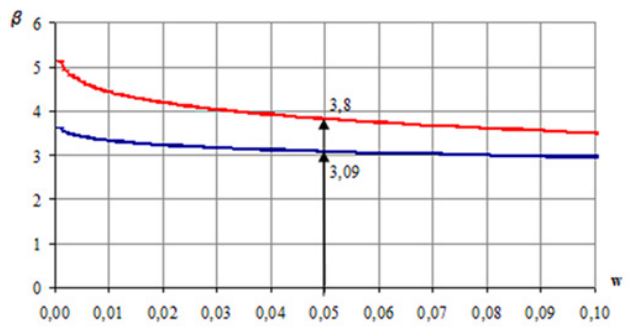

b)

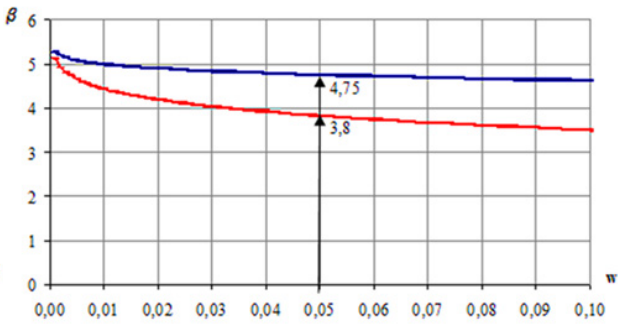

d)

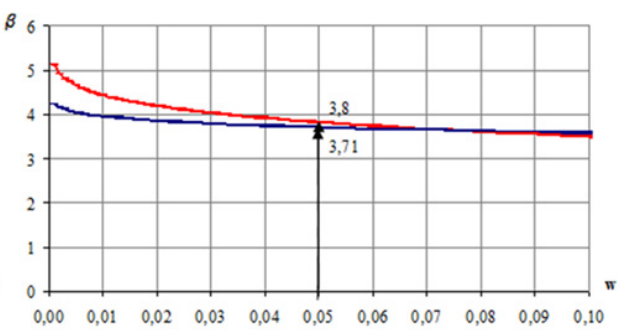

Fig. 2. The relation between the value of reliability index and the defective fraction for conformity criteria for sample size $\mathrm{n}=3$ [7] and different standard deviation $(\sigma)$ and the recommendations of PN-EN 1992 [5], a) $\sigma=2 \mathrm{MPa}$, b) $\sigma=3 \mathrm{MPa}$, c) $\sigma=3.5 \mathrm{MPa}, \mathrm{d}) \sigma=4.0 \mathrm{MPa}$, e) $\sigma=5.0 \mathrm{MPa}$,

If realized structures for which conformity control is limited to the sample size $n=3$, and the standard deviation is $5 \mathrm{MPa}$, the corresponding failure rate increases from $7.23 \mathrm{E}-05(\beta=3.8)$ to the level of 2.91-04 $\left(\beta_{\mathrm{i}}=3\right.$. 44). The level of safety for concrete structures decreases considerably when conformity control is referred to the sample size $n=3$. When analyzing the reliability of concrete 
structures, if doubtful about the quality of built-in concrete, the impact of conformity control must be taken into account, especially in the case of concrete produced with a standard deviation greater than $3.5 \mathrm{MPa}$

\section{COMPLIANCE CRITERIA AND RELIABILITY INDEX FOR REINFORCED CONCRETE STRUCTURES}

In order to determine the influence of conformity control for the sample of $n=3$, regarding sensitivity of reliability in reinforced concrete structures, calculations for two typical reinforced concrete elements were made; for a bending beam and a compressed column.

The subject of the analysis was a simply supported beam. The distance between the supports was $6 \mathrm{~m}$ and the beam was subjected to a uniformly distributed load. For permanent and variable action and material parameters the values and coefficients of variation were assumed - Table 2 .

Table 2. The values and coefficients of variation for permanent and variable action and material parameters

\begin{tabular}{|c|c|c|c|c|c|}
\hline & $\begin{array}{c}\text { characteristic } \\
\text { value }\end{array}$ & $\begin{array}{c}\text { coefficient of } \\
\text { variation }\end{array}$ & average value & design value & $\begin{array}{c}\text { standard } \\
\text { deviation }\end{array}$ \\
\hline Permanent load & $30 \mathrm{kN} / \mathrm{m}$ & $5 \%$ & $27.7 \mathrm{kN} / \mathrm{m}$ & $35.0 \mathrm{kN} / \mathrm{m}$ & $1.4 \mathrm{kN} / \mathrm{m}$ \\
\hline Imposed load & $18 \mathrm{kN} / \mathrm{m}$ & $30 \%$ & $12.0 \mathrm{kN} / \mathrm{m}$ & $27.0 \mathrm{kN} / \mathrm{m}$ & $3.6 \mathrm{kN} / \mathrm{m}$ \\
\hline Reinforced steel & $500 \mathrm{MPa}$ & $8 \%$ & $575 \mathrm{MPa}$ & $435 \mathrm{MPa}$ & $46 \mathrm{MPa}$ \\
\hline Concrete: $\mathrm{C} 25 / 30$ & $25 \mathrm{MPa}$ & - & $33 \mathrm{MPa}$ & $17.86 \mathrm{MPa}$ & $1.5-5.0 \mathrm{MPa}$ \\
\hline Concrete: $\mathrm{C} 16 / 20$ & $16 \mathrm{MPa}$ & - & $24 \mathrm{MPa}$ & $11.43 \mathrm{MPa}$ & $1.5-5.0 \mathrm{MPa}$ \\
\hline
\end{tabular}

The beam was designed in two concrete strength classes: $\mathrm{C} 25 / 30$ and $\mathrm{C} 16 / 20$, based on the following dimensions of beam cross-section: $\mathrm{h}_{1}=50 \mathrm{~cm}, \mathrm{~h}_{2}=55 \mathrm{~cm}$ and $\mathrm{b}=30 \mathrm{~cm}$, fixed for all the analysed beams. In this example, the field of tension reinforcement essential in a critical section (due to bending moment $\mathrm{M}_{\mathrm{d}}=275 \mathrm{kNm}$ ) was $1680 \mathrm{~mm} 2$ and was constant irrespective of concrete class. The reliability index for the beam was calculated by a probabilistic level 2 , using an iterative algorithm due to the nonlinearity limit state function [4]. The reliability index obtained for the critical section of bending was compared in Table 3 .

Table 3. The reliability index $-\beta$ for RC beam designed in two concrete strength classes

\begin{tabular}{|c|c|c|}
\hline Standard & The reliability index depending on concrete classes \\
\cline { 2 - 3 } deviation (MPa) & $\mathrm{C} 16 / 20$ & $\mathrm{C} 25 / 30$ \\
\hline
\end{tabular}




\begin{tabular}{|c|c|c|}
\hline 1,5 & 9.27 & 8.98 \\
\hline 2 & 8.62 & 8.57 \\
\hline 3 & 7.88 & 7.99 \\
\hline 4 & 7.48 & 7.62 \\
\hline 4.86 & 7.27 & 7.39 \\
\hline 5 & 7.24 & 7.36 \\
\hline
\end{tabular}

The calculated column was defined as a separated, internal element, stiffened by a multi-span continuous beam running the length of the column, $1=2.8 \mathrm{~m}$. This column was loaded by compressive axial force, obtained from permanent and variable action. The following material parameters were assumed in the calculation:

Permanent load: coefficient of variation $v_{\mathrm{g}}=5 \%$, load characteristic $-\mathrm{P}_{\mathrm{k}}=2222 \mathrm{kN}$, average load $\mathrm{P}_{\mathrm{m}}=2053 \mathrm{kN}$, load design $-\mathrm{P}_{\mathrm{d}}=3000 \mathrm{kN}$ and standard deviation $\sigma_{\mathrm{g}}=102.65 \mathrm{kN}$.

Imposed load: coefficient of variation $v_{\mathrm{q}}=30 \%$, load characteristic $-\mathrm{Q}_{\mathrm{k}}=952 \mathrm{kN}$, average load $-\mathrm{Q}_{\mathrm{m}}$ $=637 \mathrm{kN}$, load design $-\mathrm{Q}_{\mathrm{d}}=1000 \mathrm{kN}$ and standard deviation $\sigma_{\mathrm{q}}=191 \mathrm{kN}$.

Deadweight of column: coefficient of variation $v_{\mathrm{g}}=5 \%, \mathrm{~g}_{\mathrm{k}}=23.1 \mathrm{kN} / \mathrm{m}, \mathrm{g}_{\mathrm{k}}=25 \mathrm{kN} / \mathrm{m}, \mathrm{g}_{\mathrm{d}}=$ $33.75 \mathrm{kN} / \mathrm{m}, \sigma_{\mathrm{g}}=1.1 \mathrm{kN} / \mathrm{m}$.

Dimension parameter of column: coefficient of variation $v_{d}=5 \%, h=h_{m}, d=d_{m}, b=b_{m}$.

Due to the assumed fixed section of compression reinforcement $\left(A=9.42 \mathrm{~cm}^{2}\right)$, the cross-section of the column was changed so that the same force had met the condition of bearing capacity in all the analysed cases.

The steel and concrete material data was assumed to be the same as the analysed example of the reinforced concrete beam. A column made of two concrete classes C20/25 and C30/37 was also taken into account in the analysis. The obtained reliability index is shown in Table 4.

Table 4. The reliability index $-\beta$ for reinforced concrete column

\begin{tabular}{|c|c|c|c|c|}
\hline \multirow{2}{*}{$\begin{array}{c}\text { Standard } \\
\text { deviation (MPa) }\end{array}$} & \multicolumn{4}{|c|}{$\begin{array}{c}\text { The reliability index } \\
\text { depending on concrete class and cross-section }\end{array}$} \\
\cline { 2 - 5 } & $\begin{array}{c}\mathrm{C} 16 / 20 \\
\mathrm{~b}=\mathrm{h}=55 \mathrm{~cm}\end{array}$ & $\begin{array}{c}\mathrm{C} 20 / 25 \\
\mathrm{~b}=\mathrm{h}=50 \mathrm{~cm}\end{array}$ & $\begin{array}{c}\mathrm{C} 25 / 30 \\
\mathrm{~b}=\mathrm{h}=45 \mathrm{~cm}\end{array}$ & $\begin{array}{c}\mathrm{C} 30 / 37 \\
\mathrm{~b}=\mathrm{h}=41 \mathrm{~cm}\end{array}$ \\
\hline 1.5 & 7.38 & 7.61 & 7.70 & 7.70 \\
\hline 2 & 6.48 & 6.83 & 7.00 & 6.18 \\
\hline 3 & 5.04 & 5.49 & 5.90 & 5.26 \\
\hline 4 & 4.04 & 4.48 & 4.92 & 4.62 \\
\hline 4.86 & 3.43 & 3.84 & 4.27 & 4.53 \\
\hline 5 & 3.35 & 3.76 & 4.18 & \\
\hline
\end{tabular}




\section{CONCLUSIONS}

The level of safety for concrete structures decreases considerably when conformity control refers to the sample size $n=3$. When analyzing the reliability of concrete structures, in case of doubt about the quality of built-in concrete, the impact of conformity control must be taken into account, especially in the case of concrete produced with a standard deviation greater than $3.5 \mathrm{MPa}$.

The calculation of reliability of a bending, reinforced concrete beam showed that a change in the standard deviation in the case of application of compliance criteria for the sample size $n=3$ was not relevant for the final reliability index of the component. The resulting reliability index value is always higher than that required for a 50 -year period of use.

In the case of a compressive column made of the concrete class $C 16 / 20$ for a sample size $\mathrm{n}=3$ and a standard deviation of greater than $4 \mathrm{MPa}$, the requirements of PN-EN 1990: 2002 regarding the reliability condition are not fulfilled. In the case of a column made of concrete C20/25 for the standard deviation of the $4.86 \mathrm{MPa}$ and $5 \mathrm{MPa}$, the received reliability index of the component reaches the limit values.

The analysis of a compressive reinforced concrete column showed that reliability for reinforced concrete structures compressed analogously to concrete structures decreases significantly when compliance testing refers to the size $n=3$.

In the analysis of construction reliability, when the quality of built-in materials is doubted, compliance testing must be referred to, particularly in the case of concrete produced with a standard deviation greater than 3.5 MPa. It must be kept in mind that, in cases where the application of compliance criteria for a sample size $\mathrm{n}=3$, and a standard deviation of greater than $3.5 \mathrm{MPa}$, the achieved strength characteristic for compression is not $5 \%$ fractile. This fact has an effect on determining the reliability index of building structures.

\section{REFERENCES}

1. GOVINDARAJU K., Single sampling plans for variables indexed by AQL and AOQL, Journal of Quality Technology, Vol. 22, No. 4, pp 310-313,1990,

2. FABER M., KOEHLER J., NISHIJIMA K., Applications of Statistics and Probability in Civil Engineering, Taylor \& Francis Group, London 2011, pp. 763-764,

3. GULVANESSIAN H., HOLICKY M.: Designer's handbook to Eurocode, Thomas Telford, London 1996,

4. NOWAK A.S, COLLINS K.R: Reliability of Structures. McGraw-Hill Higher Education, 2000,

5. PN-EN 1992-1-1:2004 Design of concrete structures. General rules and rules for buildings, 2 
6. PN-EN $13670: 2009$ Execution of concrete structures,

7. PN-EN 206-1 :2000 Concrete Specification, performance, production and conformity,

8. PN-EN 1990:2002 Basis of Structural Design,

9. ISO 2394:1998 General principles on reliability for structures,

Received 15. 09. 2015

Revised 14. 10. 2015

\section{LIST OF FIGURES AND TABLES:}

Fig. 1. AOQ curve for conformity criteria for simple size $\mathrm{n}=3$ and different standard deviation, Rys.1. Średnia wadliwość po kontroli dla próby o liczebności $n=3$ i różnego odchylenia standardowego,

Fig. 2. The relation between the value of reliability index and the defective fraction for conformity criteria for simple size $\mathrm{n}=3$ [7] and different standard deviation $(\sigma)$ and the recommendations of PN-EN 1992 [5], a) $\sigma=2 \mathrm{MPa}$, b) $\sigma=3 \mathrm{MPa}$, c) $\sigma=3.5 \mathrm{MPa}$, d) $\sigma=4.0 \mathrm{MPa}$, e) $\sigma=5.0 \mathrm{MPa}$, Rys. 2. Zależność wskaźnika niezawodności od wadliwości dla kryterium zgodności n $=3$ [7] i różnego odchylenia standardowego oraz zaleceń PN-EN 1992 [5], a) $\sigma=2 \mathrm{MPa}$, b) $\sigma=3 \mathrm{MPa}$, c) $\sigma=3.5 \mathrm{MPa}$, d) $\sigma=4.0 \mathrm{MPa}, \mathrm{e}) \sigma=5.0 \mathrm{MPa}$,

Tab. 1. The value of the reliability index $\beta$ defined for the conformity criteria for the sample size $\mathrm{n}=3$ and the different classes of concrete,

Tab.1. Wartość wskaźnika niezawodności $\beta$ zdefiniowana dla kryterium zgodności $n=3$ i różnych klas betonu,

Tab. 2. The values and coefficients of variation for permanent and variable action and material parameters,

Tab. 2. Wartości i współczynniki zmienności obciążenia stałego i zmiennego oraz parametrów materiałowych,

Tab. 3. The reliability index $-\beta$ for RC beam designed in two concrete strength classes,

Tab. 3. Wartość wskaźnika niezawodności $\beta$ belki żelbetowej wyznaczonego dla dwóch klas betonu,

Tab. 4. The reliability index $-\beta$ for reinforced concrete column,

Tab. 4. Wartość wskaźnika niezawodności $\beta$ dla słupa ściskanego. 


\section{WPLYW KRYTERIÓW ZGODNOŚCI NA WARTOŚĆ WSKAŹNIKA NIEZAWODNOŚCI}

Słowa kluczowe: beton, kontrola zgodności, wskaźnik niezawodnosci, konstrukcje betonowe, element żelbetowe

\section{STRESZCZENIE:}

Kryteria zgodności dla próby o liczebności n = 3 wykazują liczne i dobrze rozpoznane wady, które mogą wpływać na obniżenie poziomu jakości produkowanego betonu, a w konsekwencji na poziom niezawodności konstrukcji betonowych oraz elementów konstrukcji żelbetowych. Efekt ten dla konstrukcji betonowych, zaprojektowanych według Eurokodu 1992, dla których wytrzymałość betonu na ściskanie jest parametrem dominującym nośności (przyjęto wskaźnik wrażliwości $\left.\alpha_{i}=0,8\right)$ określono poprzez wyznaczenie wartości wskaźnika niezawodności. W artykule ograniczono rozważania do zalecanej w normach PN-EN 1990 i ISO 2394 metody wskaźnika niezawodności $\beta$, która należy do analitycznych metod FORM (First Order Reliability Method). Zakłada się w niej, że zmienne losowe są określone za pomocą dwóch parametrów rozkładu normalnego lub ekwiwalentnego normalnego: średniej oraz odchylenia standardowego. Rozpoznane wady normowych kryteriów zgodności dotyczą głównie analiz partii (objętości) betonu przed kontrolą i odnoszą się do poziomu wadliwości podczas ciągłej produkcji betonu wyrażonych zależnością prawdopodobieństwa akceptacji od wadliwości produkowanego betonu (krzywych OC), a nie do wytrzymałości charakterystycznej betonu po wbudowaniu, a więc wadliwości po kontroli. Oszacowanie wartości charakterystycznej wytrzymałości betonu w konstrukcjach jest zależne od wadliwości betonu po kontroli. Wadliwość betonu po kontroli jest uwarunkowana przede wszystkim sformułowanymi i zalecanymi w normie PN-EN 206-1 kryteriami zgodności. Kryteria zgodności powinny być wyrazem kompromisu między wymogami niezawodności i jakości, powinny one gwarantować uzyskanie przez beton wytrzymałości charakterystycznej, zdefiniowanej jako 5\% kwantyl rozkładu statystycznego wytrzymałości na ściskanie. Zależność średniej wadliwości po kontroli od wadliwości przed kontrolą, czyli wadliwością rzeczywistą produkowanego betonu (malejącym poziomem jakości), nazywane są krzywymi średniej wadliwości po kontroli (krzywa Average Outgoing Quality - krzywa AOQ). Krzywe AOQ mogą być formą prezentacji ryzyka związanego ze stosowaniem zalecanych przez normowych kryteriów zgodności przy kontroli jakości betonu towarowego. Wykres AOQ w zależności od jakości przed kontrolą posiada ekstremum, które wyraża wartość AOQL. Graniczna średnia jakość po kontroli (Average Outgoing Quality Limit - AOQL) może być traktowana jako wielkość stanowiąca kryterium doboru planu badań, a więc weryfikowania poprawności przyjętych kryteriów zgodności. AOQL zawiera bardzo ważną informację dla odbiorcy betonu towarowego o maksymalnej wadliwości, której może się spodziewać przy sukcesywnych odbiorach szeregu partii w długim okresie czasu, w oparciu o przyjęte kryteria zgodności. Praktyczne znaczenie AOQL polega na tym, że jej wartość może być utożsamiana z poziomem kwantyla dla wytrzymałości charakterystycznej betonu na ściskanie, a więc odzwierciedlać jakość produkowanego betonu. Podstawą kwalifikacji materiału konstrukcyjnego jakim jest beton i określenia jego jakości jest wytrzymałość charakterystyczna na ściskanie $f_{c k}$ po 28 dniach dojrzewania. Wielkość $\mathrm{f}_{\mathrm{ck}}$ definiuje się jako 5\% kwantyl rozkładu statystycznego wytrzymałości betonu na ściskanie stąd graniczna wartość AOQ powinna być odniesiona do wartości 0,05. Analizę normowych kryteriów zgodności dotyczących wytrzymałości betonu na ściskanie odniesiono do wytrzymałości charakterystycznej definiowanej jako 5\% kwantyl rozkładu statystycznego badanej cechy. Do rozważań przyjęto kryteria zgodności wg PN-EN 206-1:2003 i małej liczebności próby $n=3$. Stosując podwójne kryterium zgodności dla próby o liczebności $n=3$ można zauważyć, że kształt krzywych AOQ zależy od odchylenia standardowego. Średnia wadliwość po kontroli jest tym większa im większy jest rozrzut wytrzymałości betonu na ściskanie. Maksymalna średnia wadliwość po kontroli (AOQL) dla kryteriów zgodności 
zalecanych przez PN-EN 206-1 i n=3 zależy od wartości odchylenia standardowego. Dla odchylenia standardowego powyżej 3MPa maksymalna średnia wadliwość po kontroli jest większa niż 0,05 , a więc jest większa niż rząd kwantyla dla $f_{c k}$. Zaproponowane w PN-EN 206-1 kryteria zgodności mogą prowadzić do zbyt dużego ryzyka klienta nie zapewniając odpowiedniej jakości i niezawodności realizowanych obiektów inżynierskich. Zgodnie z założeniami dla Eurokodu 2, opracowanego według badań Rackwitza, przyjęto dla wytrzymałości betonu na ściskanie odchylenie standardowe na poziomie 5MPa. Dla takiej wartości odchylenia standardowego niezależnie od liczebności próby weryfikowane partie materiału powinny uzyskać wytrzymałość charakterystyczną na poziomie ufności 0,05 i spełniać zalecenia związane z niezawodnością konstrukcji. Na podstawie przeprowadzonych analiz stwierdzono, że postać podwójnych kryteriów zgodności dla $n=3$ zaproponowanych w normie PN-EN 206-1 jest poprawna dla odchylenia standardowego do $3 \mathrm{MPa}$, w przypadku większego rozrzutu wytrzymałości na ściskanie weryfikowany beton towarowy nie spełnia wymogów projektowanej klasy betonu. W związku z wadami normowych kryteriów zgodności określono wpływ kryteriów zgodności na poziom niezawodności konstrukcji betonowych oraz elementów żelbetowych. Analizując wpływ kontroli zgodności na niezawodność konstrukcji betonowych rozpatrzono dziewięć najczęściej produkowanych klas betonów. Wpływ kryterium zgodności dla próby o liczebności $n=3$ jest szczególnie zauważalny dla betonów klas C8/10 do C30/37. Wpływ kontroli zgodności dla próby o liczebności $n=3$ na poziom niezawodności realizowanych konstrukcji z betonu jest szczególnie widoczny w przypadku, gdy odchylenie stabilizuje się na poziomie 2,0 MPa. W analizowanych przypadkach można zauważyć, że kontrola zgodności ma znaczący wpływ na wartość wskaźnika niezawodności konstrukcji betonowych, bowiem niezawodność tych konstrukcji jest uzależniona od wytrzymałości charakterystycznej na ściskanie. Rozważono również wpływ kontroli zgodności wytrzymałości betonu na ściskanie i próby o liczebności $n=3$, na poziom niezawodności elementów żelbetowych. Obliczenia przeprowadzono dla dwóch typowych elementów żelbetowych tj. zginanej belki i ściskanego słupa. Analizowana belka to belka swobodnie podparta o rozpiętości $6 \mathrm{~m}$, obciążona w sposób ciągły obciążeniem o stałej intensywności, natomiast rozpatrywany słup to wewnętrzny element wydzielony, usztywniony za pośrednictwem belki wieloprzęsłowej, wysokości $1=2,8 \mathrm{~m}$, obciążony głownie siłą ściskającą pochodzącą od obciążeń stałych i zmiennych. Przeprowadzone obliczenia niezawodności zginanej belki żelbetowej wykazały, że zmiana odchylenia standardowego w przypadku stosowania kryteriów zgodności dla próby o liczebności n=3 nie ma istotnego wpływu na docelową wartość wskaźnika niezawodności elementu. Otrzymana wartość wskaźnika niezawodności jest zawsze wyższa od wymaganej dla 50 letniego okresu użytkowania. W przypadku słupa ściskanego wykonanego z betonu klasy $\mathrm{C} 16 / 20$ dla próby o liczebności $\mathrm{n}=3$ i odchyleniu standardowym większym niż 4 MPa, nie spełnione są wymagania PN-EN 1990: 2002 odnośnie warunku niezawodności, a w przypadku słupa wykonanego z betonu C20/25 dla odchylenia standardowego 4,86 MPa i 5 MPa otrzymana wartość wskaźnika niezawodności elementu jest na granicy wartości dopuszczalnych. Przeprowadzona analiza obliczeniowa słupa żelbetowego wykazała, że niezawodność ściskanych elementów konstrukcji żelbetowych analogicznie jak betonowych, maleje wraz ze niejednorodności betonu. Niezawodność zarówno konstrukcji betonowych jak i ściskanych elementów żelbetowych zrealizowanych z betonu o odchyleniu standardowym większym od 3,0 MPa i dla którego kontrola zgodności odnoszona jest do próby o liczebności n=3 nie spełnia wymagań docelowego wskaźnika niezawodności zalecanych w PN-EN 1990. 